\begin{tabular}{|c|c|}
\hline & $\begin{array}{c}\text { Omni-Akuatika Special Issue } 3^{\text {rd }} \text { Kripik SCiFiMaS 2020: } 136 \text { - } 143 \\
\text { ISSN: } 1858-3873 \text { print / 2476-9347 online }\end{array}$ \\
\hline & Research Article \\
\hline & journal homepage: http://ojs.omniakuatika.net \\
\hline
\end{tabular}

\title{
Effects Different Human Chorionic Gonadotropine Doses for Gonads Maturity Gray Eeltailed Catfish (Plotosus canius)
}

\author{
Wiwin Kusuma Atmaja Putra*, Wenti Anggaraini, Tengku Said Raza'i, Tri Yulianto \\ Aquaculture Departement, Raja Ali Haji Maritime University, Tanjungpinang, Riau Island, Indonesia \\ *Corresponding author: wiwin.bdp@umrah.ac.id
}

Received 20 November 2019; Accepted 1 October 2020; Available online 31 December 2020

\begin{abstract}
This study aimed to determine the optimum dose of hCGto support the processing gonadal maturation of Gray Eeltailed Catfish (Plotosus canius) and to determine influencing of hCG injections treatment (quality and quantity) to TKG of Gray Eeltailed Catfish (Plotosus canius). The study was conducted in OctoberNovember 2018 in Madong, Tanjungpinang City, Riau Island. This study used a completely randomized design (RAL) method with 4 treatments that were control ( $\mathrm{NaCl}$ ), A (dose $15 \mathrm{IU} . \mathrm{Kg}^{-1}$ ), B (dose $20 \mathrm{IU} . \mathrm{Kg}^{-1}$ ), and $C$ (dose $25 \mathrm{IU} . \mathrm{Kg}^{-1}$ ) and 3 replications. Floating net cages $(\mathrm{KJA})$ with size $1 \mathrm{~m} \times 1 \mathrm{~m} \times 1 \mathrm{~m}$ as containers were used to maintain test fish. The results showed that treatment $B$ gave the best results in the study. Treatment B namely injecting hCG with a dose of $20 \mathrm{IU}_{\mathrm{Kg}}{ }^{-1}$ to reach TKG II for the whole parent, then GSI reached $0.29 \%$, but the HSI value of $A$ treatment was better on $1.93 \%$, egg diameter $1.57 \mathrm{~mm}$, fecundity reached 3,706 grains, with specific growth reaching $0.83 \mathrm{~g}$ and histologically, the gonads were characterized by the potential for a fused nucleus and filled with egg yolk and the development of the oocyte only appears smaller and more uniform in diameter.
\end{abstract}

Keyword: oocyte, female, diameter, fecundity, histology

\begin{abstract}
ABSTRAK
Penelitian ini bertujuan untuk mengetahui dosis hCG yang tepat untuk proses pematangan gonad lkan Lele Belut Abu (Plotosus canius) dan untuk mengetahui pengaruh penyuntikan hCG (kualitas dan kualitas) terhadap TKG Ikan Lele Belang Abu (Plotosus canius). Penelitian dilakukan pada bulan Oktober-November 2018 selama 30 hari di Madong, Kota Tanjungpinang, Kepulauan Riau. Penelitian ini menggunakan metode Rancangan Acak Lengkap (RAL) dengan 4 perlakuan, yaitu: kontrol $(\mathrm{NaCl})$; A (dosis 15 IU. Kg ${ }^{-1}$ ); B (dosis 20 IU. $\mathrm{Kg}^{-1}$ ) dan C (dosis 25 IU. Kg ${ }^{-1}$ ) serta 3 pengulangan. Wadah yang digunakan dalam pemeliharaan ikan uji berupa Keramba Jaring Apung (KJA) berukuran $1 \mathrm{~m} \times 1 \mathrm{~m} \times 1 \mathrm{~m}$. Hasil terbaik pada penelitian ini adalah perlakuan B yaitu dengan penyuntikan hCG dengan dosis 20 IU. $\mathrm{Kg}^{-1}$ hingga mencapai TKG II untuk seluruh induk, kemudian GSI mencapai 0,29\%, namun pada nilai HSI perlakuan A lebih baik yaitu $1,93 \%$, diameter telur $1,57 \mathrm{~mm}$, fekunditas mencapai 3.706 butir, pertumbuhan spesifik mencapai $0,83 \mathrm{~g}$ dan hasil histologis pada gonad ditandai dengan adanya nukleus yang menyatu dan terisi kuning telur dan perkembangan oosit hanya tampak lebih kecil dan seragam dalam diameter.
\end{abstract}

Kata Kunci: oosit, betina, diameter, fekunditas, histologi

\section{Introduction}

Reproduction is a problem in crossbreeding fish, especially are aspects of maturing gonad fish crossbreeding studies. Gonad maturation has been widely performed, including the potential of hormone. The hormones support regulate the process of gonad maturation (vitellogenesis) are gonadotropin (Follicle Stimulating Hormone (FSH) and Luteinizing Hormone (LH)). FSH is present in several hormone products, such as the hCG hormone. The hormone hCG plays a role of the gonad 
ripening process but in marine fish, it is used to stimulate ovulation and spawning (Nagahama, 1994). According research on the hCG hormone by Gallego et al. (2012), states that the dose of the hormone hCG reach $15 \mathrm{IU} . \mathrm{Kg}^{-1}$ to support acceleration of gonad maturity; Putra (2013) also writes that the hCG hormone induction can stimulate the maturation of eel gonads for 4 weeks at a dose of 20 IU, Putra et al. (2018) hCG showing the acceleration of the process of gonad maturation of pomfret starfish with a dose of 20 IU. This study aimed to determine the optimum dose of hCGto support the processing gonadal maturation of Gray Eeltailed Catfish (Plotosus canius) and to determine influencing of hCG injections treatment (quality and quantity) to TKG of Gray Eeltailed Catfish (Plotosus canius)

\section{Material and Methods}

\subsection{Material}

The materials of the research were Gray Eeltailed Catfish size $24 \mathrm{~cm}$ with 12 tail, hCG hormone, $\mathrm{NaCl}$ solvent, Megami feed, Gilson solvent, and formalin solvent. The research tools were microscopes, analytical scales, scalpels, floating cages, and bottles.

\subsection{Procedure}

This research method was experimental methods using Complete Randomized Design with 4 treatment and 3 replictions. The treatment research applied between control (Induction $\mathrm{NaCl}$ solvent); A (induction hCG hormone dose 15 IU. $\mathrm{Kg}^{-1}$ bodyweight) ; B (induction hormone hCG dose 20 IU. $\mathrm{Kg}^{-1}$ bodyweight) and C (induction hCG hormone dose $25 \mathrm{IU} . \mathrm{Kg}^{-1}$ bodyweight).

This research procedure were the first stage was using 4 pieces of net measuring $1 \mathrm{~m} \mathrm{x}$ $1 \mathrm{~m} \times 1 \mathrm{~m}$ as container. Then the placing of waring as a floating net cage measuring $3 \mathrm{~m} \times 3 \mathrm{~m} \times 2 \mathrm{~m}$ in the waters Madong, Kampung Bugis, Tanjungpinang City. The second stage was Fish acclimatized for 1 week. The feed given is trash fish by giving adlibitum. The fish used are female. Maintaining fish for 4 weeks (1 month) The third stage was hormone injection for every week, that we're week 0 (M0), week 2 (M2), week 3 (M3), and week 4 (M4). Dose injected as research treatment. Observations were done every week to collect the data of weighing and length body, surgery, gonad weighing and liver perform. Gonadal histology was carried in fish health laboratory, Department of Aquaculture, University IPB.

The procedures of hormon injections were fish with a maturity level of gonads between TKG 0 or TKG 1 ( maximum TKG) will be injected using hormones. Injecting was done with the intramuscular system (dorsalis). Hormone was injected evey week, namely M1 (week 1), M2 (week2), M3 (week 3) and M4 (week 4). The treatment hormone (with a availabel dose) will be given a $\mathrm{NaCl}$ sollution until the mixture of homon and $\mathrm{NaCl}$ in the syring reached $0.5 \mathrm{ml}$ before being injected into the sample fish

\subsection{Research Parameters}

\section{Gonad Maturity Level}

A gonadal maturity level is analyzed by a descriptive method on histology reference (Sukendi, 2001). Gonad Maturity level I (Ovary young): fish in the form of a pair of coarse threads located on the left and right of the abdominal cavity, clear and brownish color with a smooth surface. Gonad Maturity level II (The development): the period of the ovary is larger than TKG I, light brown, the egg granules are still not visible. Gonad Maturity level III (Adult): Ovaries are bigger than TKG II and fill half of the abdominal cavity, egg granules begin to appear, some fine grains make ovaries greenish-yellow. Gonad Maturity level IV (Matured): The ovaries have filled $2 / 3$ of the abdominal cavity, the intestines are pushed out, the color is brownish yellow and darker, the eggs look clearer and bigger than TKG III. Gonad Maturity level V (Copy): Ovary copy still looks like TKG IV, but certain parts have started to deflate because the eggs have been removed during spawning.

Gonadosomatic Index

Gonadosomatic index measurement (GSI) on the end of the study using the formula (Yalcin et al., 2001)

Table 1. Results of the parameters gonad maturaty level of Gray Eeltailed Catfish

\begin{tabular}{|c|c|c|c|c|c|}
\hline \multirow{2}{*}{ Treatment } & \multicolumn{4}{|c|}{ Fish Amount (tail) } & \multirow[t]{2}{*}{ Total (tail) } \\
\hline & TKG I & TKG II & TKG III & TKG IV & \\
\hline $\mathrm{K}$ & 2 & 1 & - & - & 3 \\
\hline$A$ & - & 3 & - & - & 3 \\
\hline$B$ & - & 3 & - & - & 3 \\
\hline $\mathrm{C}$ & 2 & 1 & - & - & 3 \\
\hline
\end{tabular}


Information:

$$
\mathrm{GSI}=(\mathrm{Wg} / \mathrm{W}) \times 100
$$

GSI : Gonadosomatic Index (\%)

Wg : Gonad Weight (g)

W : Body Weight (g)

\section{Egg Diameter}

Measurement egg diameter was done in the final week study by surgery. Egg samples were observed using an Olympus type SZX16 binocular microscope with 40 times the magnification lens and motic joints, the egg diameter expressed in millimeters $(\mathrm{mm})$.

Fecundity

Fecundity calculation by taking a small part of gonad weighed with a digital scale precision of $0.001 \mathrm{~g}$, then observed under a microscope using the add-on software Motic count manually with hand counter. The egg count results are then calculated using a formula based on:

Information:

$$
X . x=G . g
$$

$$
\begin{array}{ll}
\text { W } & \text { : Fecundity (eggs) } \\
\text { X } & \text { : Egg sample (eggs) } \\
\text { G } & \text { : Gonad weight (g) } \\
\text { g } & \text { : Gonad weight Sample (g) } \\
\text { Gonad Histology }
\end{array}
$$

\section{Gonad Histology}

Gonad histological procedures according (Diana, 2007) were Fixation: organ pieces inserted in a flakon bottle containing fixative consisting of $10 \%$ formalin for 4 to 24 hours, Washing: washing is done with $70 \%$ alcohol until it clear of fixative, Dehydrate: washing is done with $70 \%$ alcohol until it clear of fixative: $80 \%$, $90 \%, 96 \%$ alcohol were used respectively for 30 minutes, Clearing: Purification using toluol (benzoate methylicus) or toluene so that ovaries become clear for 24 hours (overnight), Infiltrate: paraffin carried out in oven/incubator at temperatures of 50 to $600^{\circ} \mathrm{C}$. Gradually first in xylol and paraffin (1:1) then pure paraffin I, II, and III for 1 hour respectively, embedding, sectioning,

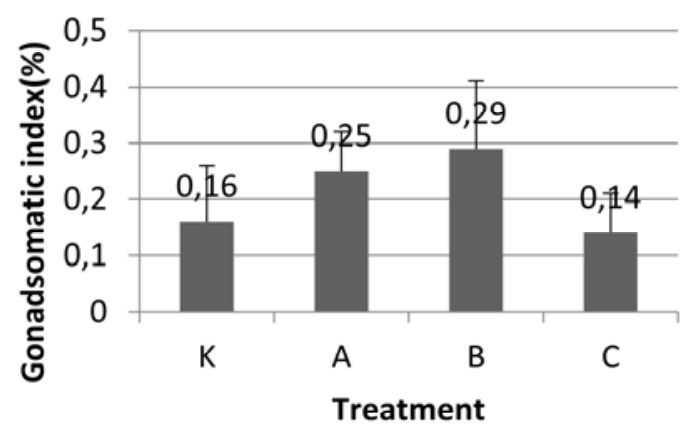

Figure 1. Gonadosomatic index of Gray Eeltailed Catfish at end the study. affixing, staining, mounting, labeling, observation, and photoshoot.

\subsection{Data analysis}

The research data of gonad maturity level, gonadosomatic index, hepatosomatic index, egg diameter, and fecundity were analyzed ANOVA and gonad histology were analyzed descriptive analysis. Results Each parameter was showed using graphs and tables.

\section{Result and Discussion}

\subsection{Gonad Maturity Level}

The treatment B with hCG dose of 20 IU. Kg1 bodyweight fish in the best treatment in this research, because gives the best response crossed fish hCG hormone induction. Whereas, the treatment $C$ is a less optimal treatment gives the prospective parent comes from nature. The response of development gonad fish maturation is influenced by the exogenous induction hormone hCG which have hormones FSH and LH (Table 1).

Senen et al. (2011) writes that gonad size first matured in different fish. The same species but different habitats give different size of mature gonads. This condition is caused by environmental and fish self factors. According to Tang and Raiman (2001) writes that the dominant environmental factors affecting gonad maturation are temperature, food, light period and season. Whereas the fish factor is the potential of hormones. Dewantoro's research (2015) using high doses of the hCG hormone and injection of hCG at a dose of $200-250 \mathrm{IU} . \mathrm{Kg}^{-}$ 1 will accelerate gonads mature of broodfish (TKG IV).

The process vitellogenesis in fish involves several hormones. The hormone of FSH (GTH I) uses to stimulate follicular development through secretion of estradiol-17 $\beta$ in ovaries and $\mathrm{LH}$

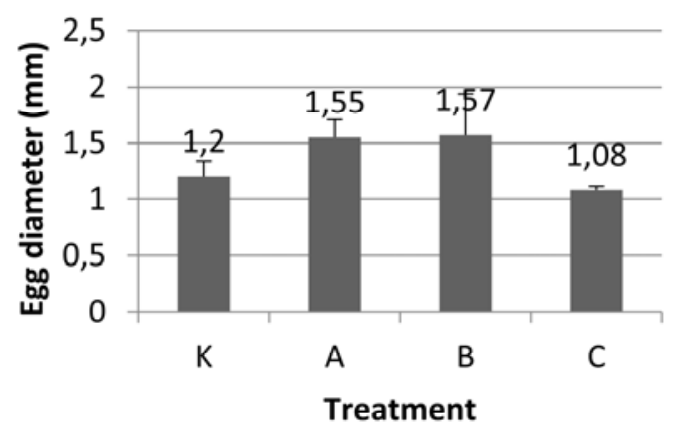

Figure 2. Eeg Diameter of Gray Eeltailed Catfish at end study 
(GTH II) is needed to support final oocyte maturation process (Nagahama 2008). Gonadotropin is produced to aid working on theca cells as place of testosterone synthesis. Testosterone is produced by theca cell layer will enter granulosa layer. Inside the testosterone granulosa layer is converted to estradiol with aromatase enzyme. Estradiol is a stimulant to support the process biosynthesis of liver vitelogenin. In addition, estradiol of blood provides back stimulation to analysis pituitary and hypothalamus of fish. Stimulation is given by estradiol to support pituitary fish as stimulus of the process gonadotropin formation. Stimulation of hypothalamus is stimulating $\mathrm{GnRH}$ process. The resulting $\mathrm{GnRH}$ works to stimulate hypofysis releasing gonadotropins which later play a role in the biosynthesis estradiol in granulosa layer. The hormonal cycle continues in the fish's body during process of vitelogenesis or gonad maturity (Nagahama 2008 and Mylonas 2010).

\subsection{Gonadosomatic Index}

The ANOVA test resulted tend of the study which stated that the treatment hCG hormone on gonad maturity of female eeltailed catfish had no significant effect or F-hit <F-tab0.05 was 1.9793 $<4.07$ on the Gonadosomatic Index parameter. The best treatment is treatment A with hCG dose of 20 IU. $\mathrm{Kg}^{-1}$ body weight of fish. The best result response of crossed fish to hCG (Figure 1). GSI values indicate the occurrence of vitellogenesis and gonadal development during study. Vitelogenesis is synthetic process of vitelogenin in liver by changing hormone estradiol- $17 \beta$. Vitelogenin is egg yolk deposited before it broken down into lipovitelin and phosvitin components of egg yolk (Kagawa et al., 2009). Vitellogenesis activity of after eggs reach maximum diameter which results increase in fish gonad weight. This vitellogenesis activity causes increasing of Hepatosomatic and gonadosomatic values. This situation support process of spawning. Atmaja (2008) states in line with growth gonad, gonad will gain weight and grow maximum size when the fish will spawn.

Stress factors as causing factor of the lack influence of the induction of treatment hormones, especially hCG on crossed fish. Fish stress is crossed is affected by cutting the fish patile crossing so that the wound that arises will increase stress and energy use for cell repair is quite large. Stress in fish can also be influenced by the environment so that it will have an impact on the hormonal process or it can also have an impact on survival (Herianti, 2005). Above factors one causes less optimal response of hCG hormone induction in treatment C (dose 25 IU).

\subsection{Egg Diameter}

Anova test results are no significant effect of the hCG hormone treatment or F-hit <F-tab 0.05 of $3.97833<4.07$ on the eeg diameter. The best treatment is treatment A with hCG dose of $20 \mathrm{IU} . \mathrm{Kg}^{-1}$ body weight of fish. Eeg diameter is the impact of the hCG hormone induction (figure 2). Increase dose hormone hCG gives effect to development crossed fish egg diameter compared to control treatment, except treatment C. This diameter also correlates with size of fish. larger size of fish, the heavier weight of gonads containing eggs (Nagahama 1994). Naturally the characteristics of crossed-out fish eggs are large diameter and yellow in final TKG (Dewanti et al. 2012). Egg diameter following the theory of influence hormone FSH which will become testosterone and then converted to estradiol and estradiol will stimulate the liver to produce lots of vitelogenin (egg yolk) (Palstra et al. 2005).

Nagahama (1994) states that increase in egg size at high doses due to accumulation vitelogenin in egg. When process vitelogenesis takes place, the yolk granules develop, both number and size so volume oocytes also enlarge, because of addition GtH I levels through injection hormone hCG into fish's body. This hormone which stimulates theka cells to produce thestosterone and pushes granulosa cells to produce enzyme aromatase convert testosterone to estradiol-17 $\beta$. Then estradiol$17 \beta$ stimulates liver to synthesize vitelogenin and results in pile egg. According to Nuraini et al. (2012), injection hormone HCG has an influence on increase in egg diameter, greater dose HCG injected greater average increase in egg

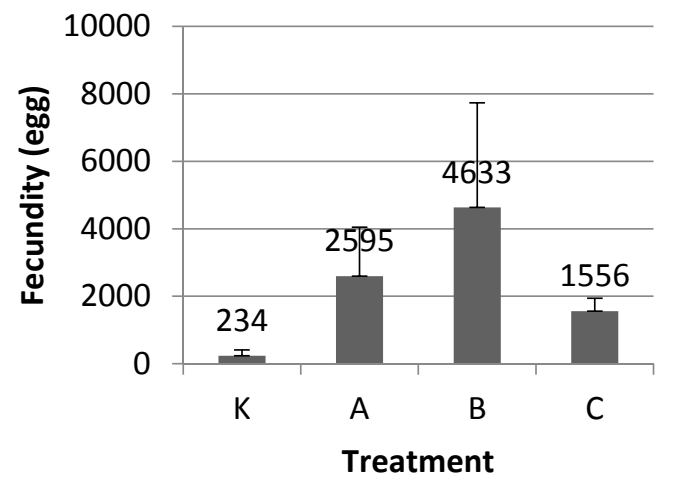

Figure 3. Fecundity of Gray Eeltailed Catfish at end study. 
diameter. The results research of Zultamin et.al (2014) diameter increased to $0.93 \mathrm{~mm}$, Nurmahdi (2005) added HCG hormone can effectively increase egg diameter baung fish from $1.30 \mathrm{~mm}$ to $1.49 \mathrm{~mm}$. According to Fani et al. (2015) mentions size egg diameter obtained in research through $\mathrm{FSH}$ intervention on cork fish resulting in diameter sizes ranging from 0.63 to $1.07 \mathrm{~mm}$.

\subsection{Fecundity}

Anova test results are no significant effect of the hCG hormone treatment or F-hit $<\mathrm{F}$-tab 0.05 of $1.771<4.07$ on the eeg diameter. The best treatment is treatment A with hCG dose of $20 \mathrm{IU} . \mathrm{Kg}^{-1}$ body weight of fish. Hormone administration with dose $20 \mathrm{IU} . \mathrm{kg}^{-1}$ has been able to increase fecundity eggs, it is directly proportional to the diameter of the egg (Figure 3). But fecundity of each fish can be different. Nikolsky (1969), in species, different ages can affect fecundity because availability of food and hormonal processes. The factors that affect fecundity are age, food supply, density, temperature, oxygen and hormonal processes of fish. Selvaraj et al. (2007), fecundity in female cork fish $C$. striatus implanted with the hormone hCG at dose $1000 \mathrm{lU} / \mathrm{Kg}$ body weight produced fecundity 15,415 and 2,245 eggs. Dewantoro (2015), injecting hCG can produce fecundity 8430-19.021. Zultamin et al. (2014), injection of
300 IU. Kg ${ }^{-1}$ hCG produced 5,772 eggs. Tahavari and Dewi (2013), hormonal induction of PMSG 20 IU. $\mathrm{Kg}^{-1}+$ HCG 10 IU. $\mathrm{Kg}^{-1}$ of Siamese catfish gives best effect on the fecundity eggs, many as 523,000 eggs.

\subsection{Gonad Histology}

The results of gonad histological analysis showed that injection of hCG could increase and uniform size egg diameter. the best treatment is treatment $A$, where eggs tend to be filled with uniform diameter, compared to treatments $\mathrm{K}, \mathrm{B}$ and $C$. Treatment $A$ has a nucleus that fused and been filled with yolk (egg). Oocyte development was seen only slightly in treatment $A$ (dose 20IU). According to Rustidja (2000), oocyte growth in the ovary can be divided into two stages, namely the primary growth stage marked by increase in size and secondary growth stage characterized by formation of visicles in cytoplasmic parifer and extending towards cell nucleus. Putra et al. (2017) in the pomfret gonad get histological picture of gonads there is uniformity in size egg, fused nucleus indicates egg has been filled with egg yolk.

According to Sjafei et al. (2008), rate of ovarian development (initial growth) is characterized by yellowish-white ovary with smooth surface. Histologically, ovary is dominated by oogonia. The nucleus is round, in middle and surrounded by phytoplasmas.
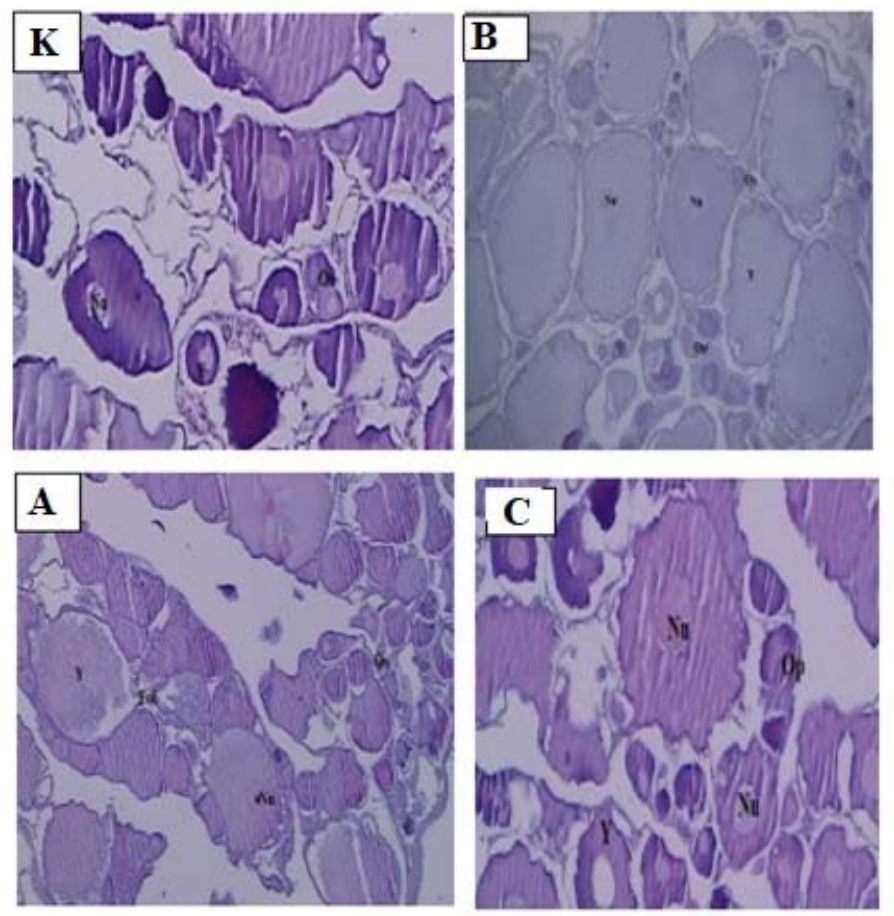

Figure 4. Histological Results of Sembilang Fish (documentation, 2018) Information Nu = Nucleus, $\mathrm{Fol}=$ follicle, $\mathrm{Y}($ yolk $)=$ egg yolk, Op = Primer Oocyte, Os = Seconder Oocyte 
ovarian development II (developing visible from bright yellow ovaries. Histologically it appears that oogonoium has largely developed into primary oocytes, this phase is called maturation. ovarian III development (adults) is indicated characteristics of bright yellow ovaries. Histologically appears that number oocytes primers increase, at this stage maturing phase begins, development of ovary IV (mature) is characterized by ovaries getting bigger, filling $2 / 3$ of the abdominal cavity (Amin 1998).

\section{Conclusion}

The conclusions of this study are the best dosage for Maturity Levels of crossed fish gonads is $20 \mathrm{IU} . \mathrm{Kg}^{-1}$ body weight. The results showed that Treatment B $\left(20 \mathrm{IU} . \mathrm{Kg}^{-1}\right)$ which reached whole parent reached TKG II when compared with Treatment $\mathrm{K}(\mathrm{NaCl}), \mathrm{A}\left(15 \mathrm{IU} . \mathrm{Kg}^{-}\right.$ $\left.{ }^{1}\right), C\left(25 \mathrm{IU} \cdot \mathrm{Kg}^{-1}\right)$. Injection of hCG can increase gonad maturity into TKG II, results of histology have a uniform egg size, cell nucleus (nucleus) that have fused and has been filled with egg yolk (yolk-egg)

\section{Acknowledgement}

We thanks for DIKTI Kemristekdikti and UMRAH to support this research with Penelitian Dosen Pemula Grant 2020), Dean Prof Dr. Agung Dhamar Syakti S.Pi DEA of Marine Science and Fisheries Faculty UMRAH and head Dr. Viktor Amrifo S.Pi M,SI of LPPM UMRAH. We would also like to thank all reviewers and all researchers for their helpful and constructive comments which greatly helped us improve this manuscript

\section{References}

Amin, M. 1998. Observation of Reproduction Techniques Applicable to the European Eel Anguilla anguilla. Alexandria (EG): National Institute of Oceanographyand Fisheries.

Cacot, P., Legendre, M. T. Q., Hung, L. T., Liem, P. T., Mariojouls. C. Lazard, J. 2002. Induced Ovulation of Pangasius bocourti Sauvage, 1880 with a Progressive hCG Treatment. Aquaculture 213(1): 199-206.

Cerda, J., Caiman, B. G., Lafleur, Jr. G., Limesand, J. S. 1996. Pattern of Vitellogenesis and Ovarian Folicular Cycle of Fundulus Heteroclitus. General and Comparative Endocrinology 103(1): 24-35.

Daves, C. J., Kovach, Ffriedlander, M. 1993. Exposure of Gracilaria to Various
Enviromental Conditions II. The Effect on Fatty Acid Composition. Botanica Marina 36(1): 289-296.

Diana, E. 2007. Tingkat Kematangan Gonad Ikan Wader Rasbora Argyrotaenia di sekitar Mata Air Ponggok Klaten Jawa Tengah. [Skripsi]. Universitas Sebelas Maret. Surakarta.

Dewanti, Y. R., Irwani, Rejeki, S. 2012. Studi Reproduksi dan Morfometri Ikan Sembilang Plotosus canius Betina yang di daratkan di Pengepul Wilayah Krobokan Semarang. Journal of Marine Research 1(2): 140.

Dewantoro, E. 2015. Keragaan Gonad Ikan Tengadak Barbonymus schwanenfeldii Setelah di injeksi Hormon hCG Secara Berkala.Jurnal Akuatika 6:1-10

Effendie, M. I. 2002. Biologi Perikanan. Yogyakarta: Yayasan Pustaka Nusatama Effendi, M.I. 1997. Biologi Perikanan. Yayasan Dewi Sri.

Fani, A. R., Bijaksana, U., Murjani, A. 2015. Intervensi Folicle Stimulating Hormone (FSH) dalam Proses Rematurasi Induk Ikan Gabus Haruan Channa striata Blkr di dalam Wadah Budidaya. Fish Scientiae 5(9): 1-14

Fibriana, C. 2010. Rekayasa Rematurasi Ikan Patin Siam P. Hypophthalmus dengan Kombinasi Penyuntikan Hormon Pmsg dan hCG Serta Penambahan Vitamin Mix 100 $\mathrm{Mg} / \mathrm{Kg}$ Pakan. [Skripsi]. Institut Pertanian Bogor.Bogor

Gallego, V., Mazzeo, I., Vílchez, M. C., Peñaranda, D. S., Carneiro, P. C. F., Pérez, L., Asturiano, J. F. 2012. Study of the Effects of Thermal Regime and Alternative Hormonal Treatments on the Reproductive Performance of European Eel Males Anguilla During Induced Sexual Maturation. Aquaculture 354: 7-16.

Harianja, M., Sukendi., Nurani. 2017. The Effect hCG (human Chorionic Gonadotropin) to Ovulation and Hatching of Fish Eggs. Jurnal Online Mahasiswa Fakultas Perikanan dan IImu Kelautan 4(2). 6-15

Hardianto, R., Razai, T. S., Putra, W. K. A. 2017. Pengaruh Hormon human Chorionic Gonadotropin (hCG) dan Pregnant Mare Serum Gonadotropin (PMSG) Terhadap Pematangan Gonad Ikan Bawal Bintang Trachinotus blochii. Intek Akuakultur 1(2): 16-22

Hismayasari, I. B., Marhendra, A. P. W., Rahayu, S., Saidin., Supriyadi, D.S. 2015. 
Gonadosomatic Index (GSI), Hepatosomatic Index (HSI) and Proportion of Oocytes Stadia as an Indicator of Rainbowfish Melanotaenia boesemani Spawning Season. International Journal of Fisheries and Aquatic Studies 2(5): 359-362

Kailasam, M., Thirunavukkarasu, A. R., Kishore, P.C., Pereira, S., Rajendran, K. V. 2006. Central Institude of Brackishwater aquaculture. New Delhi. 185-195

Lim, L.C., Heng, H. H., Lee, H. B. 1986. The Induced Breeding of Seabass Lates calcarifer in Singapore. Singapore. Jurnal Fish and Marine 14(2): 81 -95.

Muharram, D. 2016. Aspek Biologi Ikan Sembilang Plotosus canius, Bleeker 1858) di Perairan Pantai Singaraja-Majakerta, Indramayu, Jawa Barat. [Skripsi]. Institut Pertanian Bogor, Bogor.

Nagahama, Y. 1994. Endocrine Regulation of Gametogenesis in Fish.International. Jurnal Biology 38: 217-229.

Nikolsky, 1963. Habitat dan Penyebaran dan Siklus Hidup. litbang.deptan.go.perikanan

Nurmahdi, T. 2005. Pengaruh Penggunaan Hormon hCG dengan Dosis yang Berbeda Terhadap

Perkembangan Gonad Ikan Baung Hemibagrus nemurusBlkr. [Tesis S2] (Tidak dipublikasikan). Sekolah Pasca Sarjana Institut Pertanian Bogor. Bogor.

Nuraini., Alawi, H., Asiah, N., Priyatama, A.T. 2012. Induced Spawning of Selais Fish Ompok hypopthalmus Under Different Doses of Human Chorionic Gonadotropin Hormon (hCG). Jurnal Perikanan dan Kelautan. 17(2): 1-10.

Park, I. S. 2002.Induction of Ovulation by HCG, LHRHa and Carp Pituitary in Rhynchocypris oxycephalus (Sauvage and Dabry). Asian Fisheries Science. 15(1): 387-393.

Prithiviraj, N., Barath Kumar, T.R., Annadurai, D. 2012. Finding of Plotosidae - Siluriforms and its Abundance from Parangipettai Coastal Area-a Review.International Journal of Recent Scientific Research 3(6): 484.

Prihadi, D. J. 2007. Pengaruh Jenis dan Waktu Pemberian Pakan dan Tingkat Kelangsungan Hidup dan Pertumbuhan Kerapu Macan Ephinephelus. fuscogutattus dalam Keramba Jaring Apung di Balai
Budidaya Laut Lampung. Jurnal Akuakultur Indonesia 1: 493-953

Putra, W. K. A., Handrianto, R, Razai, T. S. 2018b. Maturation quality of silver pompano fish Trachinotus blochiigonad by human chorionic gonadotropin (hCG) and pregnant mare serum gonadotropin (PMSG) hormone. Journal Perikanan Universitas Gadjah Mada 19: 75-78.

Putra, W. K. A. 2017. Performa Maturasi Belut Sawah Monopterus albus yang di induksi Hormon Gonadotropin Berbeda. Intek Akuakultur 1(1): 83.

Putra, W. K. A., Hardianto, R., Raza'i, T. S. 2017. Maturasi Gonad Bawal Bintang Trachinotus blochii dengan Induksi Hormon Human Chorionic Gonadotropin (hCG) dan Pregnant Mare Serum Gonadotropin (PMSG). Jurnal Perikanan Universitas Gadjah Mada 19(2): 75-78

Putra, W. K. A., Oman, A. S., Bambang, N. P. U. 2013. Induksi Maturasi Belut Sawah Monopterus albus Dengan Hormon human Chorionic Gonadotropin dan Antidopamin. Intek Akuakultur 8(2): 219.

Randall, D. J., Donaldson, E. M. 1983. Fish Physiology. Vol. IX Part B. Academic Press, Inc, New York. 223-275.

Rahardjo, M. F., Djaja, S. S., Ridwan, A., Sulistiono. 2011. Iktiology. Bandung (ID): Lubuk Agung

Rovara, A., Affandi, R., Junior, M. Z., Agungpriyono, S., Toelihere, M. R. 2008. Pematangan Gonad Ikan Sidat Betina Anguilla bicolor Melalui Induksi Ekstrak Hipofisis. Jurnal Ilmu-ilmu Perairan dan Perikanan Indonesia 1: 69-76

Rustidja, 2000. Pemijahan Buatan Ikan-lkan Daerah Tropis. Bahtera Press. Malang.

Satyani, D., Subandiyah, S., Insan, I. 2007. Penggunaan Dua Jenis Hormon D. Gonadotropin untuk Merangsang Pemijahan Ikan Blashark Balanteocheilus melanopetrus. Lokal Riset Ikan Hias Air Tawar.

Senen, B., Sulistiono., Muchsin, I. 2011. Studi Aspek Biologi Ikan Layang Deles Decapterus macromosa di Perairan Banda Neira, Maluku. Jurnal IImiah Pertanian dan Perikanan . 8: 22-29

Sjafei, D. S., Simanjuntak, C. P. H, Rahardjo, M. F. 2008. Perkembangan Kematangan 
Gonad dan Tipe Pemijahan Ikan Selais (Ompok hypopthalmus) di Rawa Banjiran Sungai Kampar Kiri, Riau. Jurnal Iktiologi Indonesia 8(2): 93-100

Sukendi. 2001. Biologi Reproduksi dan Pengendaliannya Dalam Upaya Pembenihan Ikan Baung Mystus nemurus CV. Intitut Pertanian Bogor, Bogor.

Sumassetiyadi, M. A. 2003. Beberapapa Aspek Reproduksi Ikan Opudi Telmaterina antoniae di Danau Metano, Sulawesi Selatan. [skripsi]. Intitut Pertanian Bogor. 75

Sun, B., Pankhurst, N. W. 2004. Patterns of Oocyte Growth, Vitellogenin and Gonadal Steroid Concentrations in Greenback Flounder. Journal of Fish Biology 64: 13991412.

Tahapari, E., Dewi, R. R. S. P. S. 2013. Peningkatan Performa Reproduksi Ikan Patin Siam Pangasianodon Hypophthalmus pada Musim Kemarau Melalui Induksi Hormonal. Brita Biologi 12(2): 203-209

Takashima, F., Hibiya, T. 1995. Gonad In an Atlas of Fish Histology Normal and Pathological Features. 2nd Edited by Fumio Takhasima and T. Hibiya Kodansu LTD. 128-153.

Tang, U.M., Raiman, A., 2001. Biologi Reproduksi Ikan. Pusat Penelitian Kawasan Pantai dan Perairan Universitas Riau. Pekanbaru.

Treasurer, J. W., Holliday, F. G. T. 1981. Some Aspects of the Reproductive Biology of Perch Perca fluviatilis L. a Histological
Description of the Reproductive Cycle. Journal of Fish Biology 18(3): 359-376.

Tresnati, J. 2011. Kajian Reproduksi Ikan Bete Leiognathus equulus, Forsskal 1775) di Danau Tempe, Kabupaten Wajo, Provinsi Sulawesi Selatan. [Skripsi] Universitas Hasnuddin. Makassar

Wahyuni, L. B. 2013. Pengaruh Dosis hCG Yang Berbeda Terhadap Ovulasi dan Penetasan Telur Ikan Sepat Siam Trichogaster pectoralis. [Skripsi]. Universitas Riau. Pekanbaru. 58.

Wiadnya, Hartati, D. G. R., Suryanti, Y., Subagyo., Hartadi, A. M. 2000. Periode Pemberian Pakan yang Mengandung Kitin untuk Memacu Pertumbuhan dan Produksi Ikan Gurami Osphronemus gouramy Lac. Jurnal Penelitian Perikanan Indonesia 6(2): 62-67

Yulianto, T., Putra, W. K. A., Zulfikar., Ariska, R. 2018. Kebiasaan Makan Ikan Sembilang plotosidae pada Teluk Pengujan, Kabupaten Bintan, Kepulauan Riau. Intek Akuakultur 2(1): 35-45.

Yalcin, S., Solak, K., Akyurt, I. 2001. Certain Reproductive Characteristics of the Catfish Clarias gariepinus Burchell, 1822 Living in the River Asi, Turkey. Turkish Journal of Zoology 25: 453-460

Zultamin, Muslim, Yulisman. 2014. Pematangan Gonad Ikan Gabus Betina Channa striata Menggunakan Hormon Human Chorionic Gonadotropin Dosis Berbeda. Jurnal Akuakultur Rawa Indonesia 2(2): 162-174 